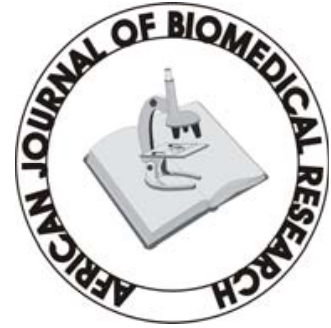

Full-text available at http://www.ajbrui.com http://www.bioline.br/md http://www.ajol.com

Received:

February, 2006

Accepted:

May, 2006

Published

January, 2007
Short communication

\section{Effect of Age on the Blood Profiles of the New Zealand Rabbit in Nigeria}

\author{
Olayemi, F.O.* and Nottidge, Helen $\mathrm{O}^{* *}$ \\ * Department of Veterinary Physiology and Pharmacology \\ University of Ibadan, Ibadan, Nigeria. \\ ** Department of Veterinary Medicine, \\ University of Ibadan, Ibadan, Nigeria.
}

\section{ABSTRACT}

The hematological and biochemical parameters of the young (4-8 week old) and adult (52-80 week-old) New Zealand rabbit were determined. The young rabbit had significantly higher plasma concentrations of creatinine $(\mathrm{P}<0.01)$, alkaline phosphatase $(\mathrm{P}<0.05)$, alanine aminootransaminase $(\mathrm{P}<0.02)$ and total protein $(\mathrm{P}<0.02)$ and mean corpuscular haemoglobin $(\mathrm{P}<0.001)$. However, the red blood cell counts, white blood cell counts, haemoglobin concentration, packed cell volume, mean corpuscular haemoglobin concentration and the plasma levels of sodium, potassium, chloride, bicarbonate, urea, albumin, albumin/globulin ratio and aspartate aminotranferase were similar in the young and adult rabbit. (Afr. J. Biomed. Res. 10:99 - 102, January 2007)

Keywords: Age, blood cells, rabbit

*Address for Correspondence: e-mail: funsho_olayemi@yahoo.com;

\title{
INTRODUCTION
}

Abstracted by:

African Index Medicus (WHO), CAB Abstracts, Index Copernicus, Global Health Abstracts, Asian Science Index, Index Veterinarius, Bioline International , African Journals online 
The influence of age on the blood parameters of animals have been determined in several species of mammals for example in the White Fulani cattle (Oduye and Okunaiya, 1971); Nigerian goat and sheep (Oduye, 1976); Nigerian local dog (Awah and Nottidge, 1998) and the African giant rat (Nssien et al, 2002).

The New Zealand rabbit are very popular in this country as they are extensively used in the laboratories for research and also consumed with relish by a large segment of the population.

Jain (1986) compared some erythrocyte values in the adult and young New Zealand rabbit. There is a dearth of information in the literature concerning the plasma biochemical values of the New Zealand rabbit. Therefore the aim of this study is to have a baseline plasma biochemical values in our environment.

\section{MATERIALS AND METHODS}

Eighteen New Zealand rabbits were used for this study. The first group consisted of ten adult rabbits of both sexes with ages ranging between 52 and 80 weeks. The second group consisted of eight unsexed young rabbits between 4 to 8 weeks old. They were reared on a farm in Ibadan, Ibadan, Nigeria. They were given rabbit pellets and drinking water ad libitum.

Each rabbit was anaesthetized with either. Blood was then collected from the orbital sinus into bottles containing ethylene diamine tetraacetic acid (EDTA) $2 \mathrm{mg} / \mathrm{ml}$ of blood as anticoagulant. Red blood cell (RBC) and white blood cell (WBC) counts were determined using a haemocytometer. The packed cell volume (PVC) was estimated by the microhaematocrit method. Haemoglobin (Hb) concentration was measured by the cyanmaethmoglobin method. From the data generated on the $\mathrm{Hb}, \mathrm{RBC}$ and $\mathrm{PVC}$, the mean corpuscular volume (MCV), mean corpuscular haemoglobin $(\mathrm{MCH})$ and mean corpuscular haemoglobin concentration (MCHC) were calculated (Jain, 1986).

The blood samples from the adult and young rabbits were centrifuged at 3000G for 10 mins to obtain plasma. The sodium (Na) and potassium (k) concentrations in the plasma were determined by standard flame photometry. Calcium (Ca) and bicarbonate (HCO3) were determined by the method of Toro and Ackeermann (1975). Chloride (Cl) was estimated by the method of schales (1941). Total protein was determined by the Biuret method of Reinhold (1953) and albumin by the method described by Doumas et al. (1971). Globulin was calculated by subtracting albumin from total protein. Urea and creatinine were determined according to methods of Harrison (1947). Activities of aspartate aminootran aminase (AST) and alanine aminotransaminase (ALT) were determined colorimetrically by the method described by Mohunn and Cook (1957). Alkaline phosphatase (ALP) was determined according to the method of King and Armstrong (1934). The results were statistically evaluated using the Student's t-test with $\mathrm{p}<0.05$ taken as significant.

\section{RESULTS}

Table 1 shows the effect of age on the RBC, WBC, $\mathrm{PVC}, \mathrm{Hb}, \mathrm{MCV}, \mathrm{MCH}$ and $\mathrm{MCHC}$ values in the New Zealand rabbits. The mean values of RBC, WBC, PVC, $\mathrm{Hb}$ and MCHC were similar in the young and adult. However, the values of MCV and $\mathrm{MCH}$ were higher $(\mathrm{P}<0.001)$ in the adult than in the young rabbit.

\section{Table 1}

Erythrocye values and total white blood cell count (mean \pm sd) in the young and adult New Zealand rabbit

\begin{tabular}{lll}
\hline PARAMETERS & $\begin{array}{c}\text { YOUNG } \\
\mathbf{n = 8}\end{array}$ & $\begin{array}{c}\text { ADULT } \\
\mathbf{n}=\mathbf{1 0}\end{array}$ \\
\hline $\mathrm{RBC}(\mathrm{X} \mathrm{10} / \mathrm{\mu l})$ & $8.38 \pm 2.30$ & $6.23 \pm 2.02$ \\
\hline $\mathrm{PCV}(\%)$ & $30.13 \pm 6.10$ & $34.60 \pm 5.72$ \\
\hline $\mathrm{Hb}(\mathrm{g} / \mathrm{dl})$ & $9.73 \pm 1.96$ & $11.98 \pm 1.33$ \\
\hline $\mathrm{MCH}(\mathrm{pg})$ & $11.99 \pm 2.31$ & $19.25 \pm 4.64^{*}$ \\
\hline $\mathrm{MCHC}(\mathrm{g} / \mathrm{dl})$ & $32.30 \pm 0.70$ & $32.82 \pm 2.55$ \\
\hline $\mathrm{MCV}(\mathrm{fl})$ & $37.11 \pm 7.21$ & $58.94 \pm 14.14^{*}$ \\
\hline $\mathrm{WBC}(\mathrm{X} \mathrm{10} / \mathrm{\mu l})$ & $5.20 \pm 2.07$ & $3.95 \pm 0.98$ \\
\hline Value significantly different from young at $* P<0.001$
\end{tabular}


African Journal of Biomedical Research 2007 (Vol. 10) / Olayemi and Nottidge

Table 2

Plasma biochemical values (mean \pm sd) in the young and adult New Zealand rabbit

\begin{tabular}{|c|c|c|}
\hline PARAMETERS & YOUNG (n) & ADULT (n) \\
\hline Sodium (mmol/l) & $\begin{array}{l}172.14 \\
\pm 21.99(7)\end{array}$ & $\begin{array}{l}163.90 \\
\pm 4.89(10)\end{array}$ \\
\hline Potassium (mmol/l) & $\begin{array}{l}40.74 \\
\pm 17.77(7)\end{array}$ & $\begin{array}{l}25.22 \\
\pm 3.52(10)\end{array}$ \\
\hline Chloride (mmol/l) & $\begin{array}{l}131.33 \\
\pm 11.55(3)\end{array}$ & $\begin{array}{l}137.50 \\
\pm 10.45(9) \\
\end{array}$ \\
\hline $\begin{array}{l}\text { Bicarbonate } \\
(\mathrm{mmol} / \mathrm{l})\end{array}$ & $\begin{array}{l}16.67 \\
\pm 2.89(3) \\
\end{array}$ & $\begin{array}{l}18.89 \\
\pm 2.89(9) \\
\end{array}$ \\
\hline AST (i.u/l) & $\begin{array}{l}54.29 \\
\pm 15.05(7)\end{array}$ & $\begin{array}{l}38.67 \\
\pm 16.42(9)\end{array}$ \\
\hline ALT(i.u/l) & $\begin{array}{l}73.14 \\
\pm 14.59(7)\end{array}$ & $\begin{array}{l}107.00 \\
\pm 34.20(9)^{*}\end{array}$ \\
\hline Total protein (g/dl) & $\begin{array}{l}5.01 \\
\pm 0.65(7) \\
\end{array}$ & $\begin{array}{l}5.83 \\
\pm 0.55(10)^{*}\end{array}$ \\
\hline $\operatorname{Albumin}(\mathrm{g} / \mathrm{dl})$ & $\begin{array}{l}3.73 \\
\pm 0.32(7)\end{array}$ & $\begin{array}{l}4.10 \\
\pm 0.42(10)\end{array}$ \\
\hline Globulin (g/dI) & $\begin{array}{ll}1.29 & \pm \\
0.38(7) & \\
\end{array}$ & $\begin{array}{l}1073 \\
\pm 0.18(10)^{*}\end{array}$ \\
\hline $\begin{array}{l}\text { Albumin/globulin } \\
\text { ratio }\end{array}$ & $\begin{array}{l}3.16 \\
\pm 1.09(7)\end{array}$ & $\begin{array}{l}2.38 \\
\pm 0.21(10)\end{array}$ \\
\hline Urea(mg/dI) & $\begin{array}{l}23.29 \\
\pm 10.03(7) \\
\end{array}$ & $\begin{array}{l}32.50 \\
\pm 7.14(10) \\
\end{array}$ \\
\hline Creatinine (mg/dl) & $\begin{array}{l}1.24 \\
\pm 0.15(7) \\
\end{array}$ & $\begin{array}{l}1.58 \\
\pm 0.21(10) * *\end{array}$ \\
\hline ALP (i.u/l) & $\begin{array}{l}25.33 \\
\pm 21.50(3) \\
\end{array}$ & $\begin{array}{l}2.57 \\
\pm 2.15(7)^{* * *} \\
\end{array}$ \\
\hline
\end{tabular}

Table 2 presents the plasma biochemistry values in the young and adult New Zealand rabbits. $\mathrm{Na}, \mathrm{K}, \mathrm{Cl}$, $\mathrm{HCO}_{3}$, urea, albumin, AST and albumin/globulin ratio were similar in the young and adult. The young rabbit however had higher concentrations of creatinine $(\mathrm{P}<0.01)$, ALP $(\mathrm{P}<0.05)$, ALT $(\mathrm{P}<0.02)$, Total protein $(\mathrm{P}<0.02)$ but lower levels of globulin $(\mathrm{P}<0.02)$ than the adult rabbit.

\section{DISCUSSION}

The RBC counts of $6.83 \times 10^{6} / \mu$ l obtained for the adult New Zealand rabbit of the present study was similar to the RBC value of $6.05 \times 10^{6} / \mu \mathrm{l}$ obtained by Jain (1986) in the same species of rabbit and the value of $6.88 \times 10^{6} / \mu$ l reported for the laboratory rat (Oyewale, 1987). However Dina et al. (2002) reported a lower $\mathrm{RBC}$ value of $5.05 \times 10^{6} / \mu \mathrm{l}$ in the same species of rabbit.

In the present study, the values of RBC, PCV, $\mathrm{Hb}$, $\mathrm{MCV}, \mathrm{MCH}$ and MCHC and WBC were similar in the young and adult New Zealand rabbit. This observation is also similar to that made in the Jack rabbit (Jain, 1986), Aryshire cattle (Tashjan, 1968) and Nigerian local cat (Nottidge et al., 1999) in which similar values were reported in the young and adult. Oduye and Okunaiya (1971) also did not observe any age difference in the values of PCV, Hb and WBC of the White Fulani cattle. However, dogs that were less than 3 months were found to have lower PCV than adult dogs (Oduye, 1978). Olusanya (1979) reported that MCV increased with age while WBC counts decreased with age in the White Fulani cattle.

There was no age difference in the mean values of plasma electrolytes ( $\mathrm{Na}, \mathrm{K}, \mathrm{Cl}$ and $\mathrm{HCO}_{3}$ ) in the New Zealand rabbit. Nottidge et al. (1999) similarly did not observe any age differences in the values of $\mathrm{Na}, \mathrm{K}, \mathrm{Cl}, \mathrm{Ca}, \mathrm{PO}_{4}$ and $\mathrm{HCO}_{3}$ of the Nigerian local cat. Nssien et al. (2002) reported that the values of $\mathrm{Na}, \mathrm{Cl}$ and $\mathrm{HCO}_{3}$ were similar in the young and adult African giant rat, however the plasma levels of $\mathrm{K}$ and $\mathrm{Ca}$ were higher while $\mathrm{PO}_{4}$ was lower in the adult than in the young rat (Nssien et al., 2002). In the present study the young New Zealand rabbit had higher plasma creatinine, ALP, ALT, total protein but lower plasma globulin than the adult, however the levels of AST, albumin,/globulin ratio and urea were similar in the young and adult New Zealand rabbit. Nottidge et al. (1999) reported that the serum levels of total protein, albumin, globulin, ALP, AST, ALT, urea, albumin/globulin ratio and cratinine were similar in the young and adult Nigeria

\section{REFERENCES}

Awah, J.N. and Nottidge, H.O. (1998): Serum biochemical parameters in clinically healthy dogs in Ibadan. Trop. Vet. 16, 123-129

Dina, O.A., Saba, A.B., Adedapo, A.A., Akinyemi, O.M. and Omobowale, T.O. (2002): Comparative efficacy study of homidium bromide, diminazine aceturate and their combination in New Zealand white rabbits 
experimentally infected with Trypanosoma congolense. Trop. Vet. 20, 153-158

Harrison, G.A. (1947): Chemical methods in clinical medicine $3^{\text {rd }}$ ed. Churchill. London.

Jain, N.C. (1986): Schalm's Veterinary Haematology, $4^{\text {th }}$ Ed. Lea and Febiger, Philadelphia, U.S.A.

King E.J. and Armstrong, A.R. (1934): A convenient method for determining serum and bile phosphates activity. Can. Med. Assoc. J 31, 376-381

Mohun, A.E. Cook, P. (1957): Simple method for measuring serum levels of the glutamateoxaloacetate and glutamic pyruvic transaminase in the routine laboratory. J. Clin. Path. 10, 374-399.

Nottidge, H.O., Taiwo, V.O. and Ogunsanmi, A.O. (1999): Haematological and serum biochemical studies of cats in Nigeria. Trop. Vet. 17, 9-16.

Nssien, M.A.S., Olayemi, F.O., Onwuka, S.K. and Olusola A. (2002): Studies on some plasma biochemical parameters in the African giant rat (Cricetomys gambianu, Waterhouse). Afr. J. of Biomed. Res. 5, 63-68.

Oduye, O.O. (1976): Haematological values of Nigerian goats and sheep. Trop. Anim. Hlth. Prod. 8, 131-136.

Oduye, O.O., (1978): Haematological studies on clinically normal dogs in Nigeria. Zbl. Vet. Med. 25, 548555.
Oduye, O.O., O.A. Okunaiya (1971): Haematological studies on the white Fulani and N'dama breeds of cattle. Bull. Epizoot. Dis. Afr. 19: 213-218.

Olusanya, S.K. (1979): Studies on some blood and body fluid characteristics in Zebu and European breeds of cattle in hot humid tropics of Nigeria. Bull. Anim. Hlth. Prod. Afri. 27, 231-236.

Oyewale, J.O. (1987): Studies on the erythrocytes osmotic fragility of rats infected with Trypanosoma brucei. Anim. Tech., 38, 219-228

Reinhold, J.G. (1953): Mannual determination of serum total protein albumin and globulin fractions by Buiret method. In Standard Method of Clinical Chemistry(ed) M. REINER; Academic Press, New York, pp 88,

Schales, O. and Schales, S.S. (1941): A simple and accurate method for the determination of chloride in biological fluids. J. Biol Chem. 140, 879-884,

Teshjian, R.J., Snyder, J.W. and Das, K.M. (1968): Blood studies of 32 clinically normal Ayrshire cattle. Cornell Vet. 58, 8-11.

Toro, G. and Ackermann, P. (1975): Pratical Clinical Chemistry. $1^{\text {st }}$ ed. Little Brown and Company Boston. Pp 237-238,. 